\title{
The Impact of IT Application Control on the quality of the Audit Evidence: An Application Example
}

\author{
Bilgi Teknolojileri Uygulama Kontrollerinin Denetim Kanıtının \\ Kalitesine Etkisi: Bir Uygulama Örneği
}

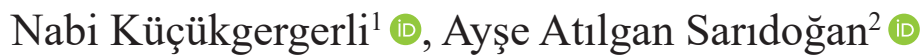 \\ ${ }^{1}$ Assist. Prof., İstanbul Health and Technology University, Faculty of Economics and Administrative Sciences, İstanbul, Turkey. \\ E-mail: nabi.kucukgergerli@istun.edu.tr \\ ${ }^{2}$ Assist. Prof., Çanakkale Onsekiz Mart University, Çanakkale Vocational School of Health Sciences, Çanakkale, Turkey. \\ E-mail: aysesaridogan@comu.edu.tr \\ ORCID: N.K. 0000-0003-2995-5188; A.A.S. 0000-0001-5160-7687
}

\begin{abstract}
In recent years, firms have started to invest millions of dollars on information technologies for a number of reasons, such as managing their operations more effectively, expanding trade channels, and preventing fraudulent activities. Parallel to these investments in IT, financial reporting processes have undergone serious changes. In addition to the creation of all accounting records that have bases on financial statement items with different IT applications, factors such as the expansion and diversification of companies' operations have made it difficult to audit accounting records with classical methods. In the past, while accounting records were created by people in the classical way, thousands of records could be created automatically very quickly thanks to IT applications. For this reason, the reliability of audit evidence obtained by ignoring IT application controls has become questionable. In this study, first of all, the effect of IT on audit processes and audit evidence has been explained. Then, IT application control tests were applied in a manufacturing enterprise and the effect of the obtained audit evidence on the audit was investigated. Since our paper is one of the first studies to examine the effects of IT practices on audit quality in the literature, it will lead the further studies.
\end{abstract}

Keywords: IT Audit, IT Application Control, ITGC

\section{öz}

Firmalar, son yıllarda operasyonlarını daha efektif yönetmek, ticaret kanalları genişletmek, suiistimalleri engellemek gibi birtakım nedenlerden ötürü bilgi teknolojilerine milyonlarca dolar para harcamaktadırlar. BT’ye yapılan bu yatırımlara paralel olarak, finansal raporlama süreçleri de ciddi değişikliklere uğramıştır. Finansal raporlama süreçleri eskiden tek bir uygulama kullanılarak yönetilebilirken, günümüzde neredeyse finansal tabloları oluşturan bütün kalemler BT 'ye entegre edilen farklı uygulamalar ile yönetilmeye başlanmıştır. Finansal tablo kalemlerinin temelini oluşturan muhasebe kayıtlarının neredeyse tamamının farklı BT uygulamaları ile oluşturulmasına ek olarak firmaların operasyonlarının genişlemesi ve çeşitlenmesi gibi etkenlerde muhasebe kayıtlarının klasik yöntemler ile denetimini zorlaştırmıştır. Muhasebe kayıtları önceden insanlar tarafından klasik olarak oluşturulurken, BT uygulamaları sayesinde binlerce kayıt çok hızlı bir şekilde otomatik olarak oluşturulmaktadır. Bu nedenle, BT uygulama kontrollerinin göz ardı edilerek elde edilen denetim kanıtlarının güvenirliği sorgulanır hale gelmiştir. Bu çalışma da öncelikle BT’nin denetim süreçlerine ve denetimin kalitesine etkisi açıklanmış daha sonra bir üretim işletmesinde BT uygulama kontrol testleri uygulanmış ve elde edilen denetim kanıtlarının denetime etkisi araştırılmıştır. Çalışmamız da BT uygulamaların denetim kalitesine etkisini literatürde inceleyen ilk çalışmalardan biri olması nedeniyle sonraki çalışmalara öncelik edecektir.

Anahtar kelimeler: Bilgi teknolojileri denetimi, Bilgi teknolojileri uygulama Kontrolleri, BT Denetimi

Submitted/Başvuru: 07.11.2021 Revision Requested/Revizyon Talebi: 07.12.2021 Last Revision Received/Son Revizyon: 15.12.2021 Accepted/Kabul: 19.12.2021 Corresponding author/Sorumlu yazar: Nabi Küçükgergerli / nabi.kucukgergerli@istun.edu.tr

Citation/Atıf: Kucukgergerli, N. \& Atilgan Saridogan, A. (2022). The impact of IT application control on the quality of the audit evidence: an application example. Muhasebe Enstitüsü Dergisi - Journal of Accounting Institute, 66, 65-77. https://doi.org/10.26650/MED.1020306 


\section{Introduction}

Developments in information technologies (IT), monitoring whether the activities in the value chain are carried out in accordance with the planned objectives, principles, legislation and standards have made the use of intelligent autonomous decision support systems widespread in auditing processes. Developments in information technologies make significant contributions to the development of auditing. It is foreseen that the management of routine transactions, especially in auditing, with smart systems will gain depth and prevalence. Likewise, it is expected that data analytics techniques will be used more intensively in audit processes, and more effective risk management will be achieved in auditing. In terms of technological developments, principles, standards and auditors, which are the components of auditing, it is clear that the compatibility and complementarity of developments in these areas will make significant contributions to more effective and efficient auditing processes. Effective design and implementation of the necessary education and training processes for the new generation auditing processes is also important in terms of preventing disruptions in this area.

In this study, first of all, the effect of IT on audit processes and audit evidence was explained. Then, IT application control tests were applied in a manufacturing enterprise and the effect of the obtained audit evidence on the audit was investigated.

\section{The Impact of IT Application Control on Audit Processes}

Technological changes have a significant impact on business and analysis processes and decision-making techniques in the field of accounting and auditing. The development process of auditing technologies is given in Table 1. Accordingly, audit processes made with pencil, paper and calculator are moving towards more advanced autonomous intelligent systems and software.

\begin{tabular}{|l|l|}
\hline \multicolumn{2}{|l|}{ Table 1: Timeline of Audit Technologies } \\
\hline Period & Audit Technologies \\
\hline Before 1970 & Pencil, Calculator \\
\hline $1970-1980$ & Computer and related tools \\
\hline $1980-1990$ & Expert Systems \\
\hline & $\begin{array}{l}\text { Computer Assisted, Computer Assisted Audit Tools and Techniques (CAATT), (Electronic working papers, word } \\
\text { processing and spreadsheet applications) }\end{array}$ \\
\hline $1990-2000$ & \\
\hline & Generalized audit software (GAS), Continuous controls monitoring (CCM) \\
\hline $2000-2010$ & $\begin{array}{l}\text { Certification in Risk Management Assurance (CRMA), Data analytics, Data Mining, Data Visualization, Internet of } \\
\text { Things, Industry 4.0, Blockchain, Audit App, Drones, .... }\end{array}$ \\
\hline 2010-2020 & \\
\hline \multicolumn{2}{|l|}{$\begin{array}{l}\text { Source: Dai, J. (2017). Three essays on audit technology: audit 4.0, blockchain, and audit app (Doctoral dissertation, Rutgers University-Graduate } \\
\text { School-Newark) }\end{array}$} \\
\hline
\end{tabular}

The development stages of the audit are given in Table 2. Accordingly, the development stages of the audit are divided into four stages. Audit systems are moving from manual auditing, using paper, pencil and calculator, to making processes for auditing with more intensive computer-aided intelligent systems depending on the developments in information and communication technology over time. In this context, in the Audit 2.0 stage, software and programs such as Excel, CAAT software and audit technologies have progressed. In the process defined as Audit 3.0, there was a more intensive application of big data and analytical techniques to audit processes. In the phase defined as Audit 4.0, partially or completely autonomous smart information technologies have been used intensively in audit processes and decision support mechanisms. 
Table 2: The Generations of the Audit

\begin{tabular}{|l|c|c|c|c|}
\hline Generations & Audit 1.0 & Audit 2.0 & Audit 3.0 & Audit 4.0 \\
\hline Characteristic & Manual audit & IT audit & $\begin{array}{c}\text { Inclusion of Big Data in audit } \\
\text { analytics }\end{array}$ & $\begin{array}{c}\text { Semi- and progressive } \\
\text { automation of audit }\end{array}$ \\
\hline Tools & $\begin{array}{c}\text { pencils, } \\
\text { calculators }\end{array}$ & Excel, CAAT software & Analytical apps & $\begin{array}{c}\text { Sensors, CPS, IoT/IoS, } \\
\text { RFID, GPS }\end{array}$ \\
\hline
\end{tabular}

Source: Dai, J., \& Vasarhelyi, M. A. (2016). Imagineering Audit 4.0. Journal Of Emerging Technologies In Accounting, 13(1), 1-15

The difference between traditional and artificial intelligence (AI) and the audit process is given in Table 3. Accordingly, at all stages of the audit process, the artificial intelligence-supported audit process collects, processes and contributes to the reporting processes with continuous instant smart algorithms. Intelligent autonomous artificial intelligence algorithms, which have the ability to process and report higher volumes of data more intensively according to audit needs, make significant contributions to auditors' more effective decision making.

Table 3: Comparison Between AI Audit Process and Traditional Audit Process

\begin{tabular}{|c|c|c|}
\hline Phase & AI-Enabled Automated Audit Process & Traditional Audit Process \\
\hline Pre-Planning & $\begin{array}{l}\text { - AI collects and analyzes Big Data (exogenous) } \\
\text { - Data related to the client's organizational structure, } \\
\text { operational methods, and accounting and financial systems is } \\
\text { fed into the AI system }\end{array}$ & $\begin{array}{l}\text { - Auditor examines client's industry } \\
\text { - Auditor examines client's organizational structure, } \\
\text { operational methods, and accounting and financial } \\
\text { systems }\end{array}$ \\
\hline Engagement & $\begin{array}{l}\text { - AI uses the estimate of the risk level (from Phase 1) and } \\
\text { calculates audit fees and the number of hours } \\
\text { - AI analyzes a database of contracts and prepares the } \\
\text { contract } \\
\text { - Auditor and client sign contract }\end{array}$ & $\begin{array}{l}\text { - Engagement letter is prepared by the auditor- based on } \\
\text { the estimated client risk } \\
\text { - Auditor and client sign the contract }\end{array}$ \\
\hline \begin{tabular}{l|} 
Understanding \\
Internal \\
Controls and \\
Identifying \\
Risk Factors
\end{tabular} & $\begin{array}{l}\text { - Feed flowcharts, questionnaire answers, and narratives into } \\
\text { the AI system and use image recognition and text mining to } \\
\text { analyze them } \\
\text { - Use drones to conduct the walkthrough, then use AI to } \\
\text { analyze the generated video } \\
\text { - Use visualization and pattern recognition to identify risk } \\
\text { factors } \\
\text { - AI aggregates all these data to identify fraud and illegal- } \\
\text { acts risk factors }\end{array}$ & $\begin{array}{l}\text { - Document understanding (flowcharts, questionnaires, } \\
\text { narratives, walkthrough) } \\
\text { - Auditor aggregates this information and uses their } \\
\text { judgment to identify risks factors } \\
\text { - Understanding of Internal Control (IC) to determine } \\
\text { the scope, nature, and timing of substantive tests }\end{array}$ \\
\hline $\begin{array}{l}\text { Control Risk } \\
\text { Assessment }\end{array}$ & $\begin{array}{l}\text { - Continuous control monitoring systems examine controls } \\
\text { continuously } \\
\text { - AI runs process mining to verify proper IC implementation } \\
\text { - Logs are automatically generated to ensure their integrity }\end{array}$ & $\begin{array}{l}\text { - Examination of the client's IC policies and procedures } \\
\text { - Risk assessment for each attribute } \\
\text { - Test of controls } \\
\text { - Risk reassessment } \\
\text { - Document testing of controls }\end{array}$ \\
\hline $\begin{array}{l}\text { Substantive } \\
\text { Tests }\end{array}$ & $\begin{array}{l}\text { - Continuous Data Quality Assurance ensures quality of data } \\
\text { and evidence } \\
\text { - AI examines data provenance } \\
\text { - Continuous test of details of transactions on } 100 \% \text { of the } \\
\text { population } \\
\text { - Continuous test of details of balances (at all times) } \\
\text { - Continuous pattern recognition, outlier detection, } \\
\text { benchmarks, and visualization }\end{array}$ & $\begin{array}{l}\text { - Periodical sampling-based tests, and nature, extent, } \\
\text { and timing depend on IC tests } \\
\text { - Tests of details of a sample of transactions } \\
\text { - Test of details of balances (at a certain point in time) } \\
\text { - Analytical procedures }\end{array}$ \\
\hline $\begin{array}{l}\text { Evaluation of } \\
\text { Evidence }\end{array}$ & - This becomes part of the previous phase & $\begin{array}{l}\text { - Auditor must evaluate the sufficiency, clarity, and } \\
\text { acceptability of collected evidence. Accordingly, auditor } \\
\text { may either collect more evidence, or withdraw from the } \\
\text { engagement }\end{array}$ \\
\hline Audit Report & $\begin{array}{l}\text { - AI uses a predictive model to estimate the various risks } \\
\text { identified } \\
\text { - Audit report can be continuous (graded 1-00 for example) } \\
\text { rather than categorical (clean, qualified, adverse, etc.) }\end{array}$ & $\begin{array}{l}\text { - Auditor aggregates previous information to issue a } \\
\text { report } \\
\text { - Report is categorical: clean, qualified, adverse, etc. }\end{array}$ \\
\hline
\end{tabular}


IT-based software applications have an increasing importance in audit processes. Owing to IT technologies, millions of routine transactions, information and documents in the audit processes can be audited and verified more efficiently. Although the experience and common sense of the auditors are still vital in the sensitive issues of the audit processes, IT supported audit processes and results also provide important contributions to the auditors (See, Sayana 2002, Padayachee \& De Jager 2015, Fowler \& Mar 2017, Karya \& Moertini 2013, Henderson et al 2013, Chen 2011)

Jakšić (2009) stated various tools and techniques based on computers used in audit processes can be used. Thanks to the use of information technologies in audit processes, internal controls can be verified, records can be accessed and processes can be completed with high efficiency. The most important computer-assisted audit techniques are:

1. Test data, 2. Integrated testing facility, 3. Parallel simulation and 4. Online audit monitor.

Bellino et al (2007) stated that the IT Application Control has control over the scope of individual business processes or application systems, including data orchestrations, segregation of business functions, balancing of transaction totals, transaction logging and error reporting. Testing application controls makes a positive contribution to time savings, increased audit quality, reduced costs, increased security, reduced risks, and efficiency. Application controls cover the following purposes:

- The correct, complete, authorized and correctness of the entered data,

- The data is processed as intended within a reasonable time frame,

- The stored data is correct and complete,

- The outputs are correct and complete,

- A record is kept to monitor the data process from input to storage and final output,

Figure 1. shows the key elements of focus for application audits from data input to data output by considering all the processes.

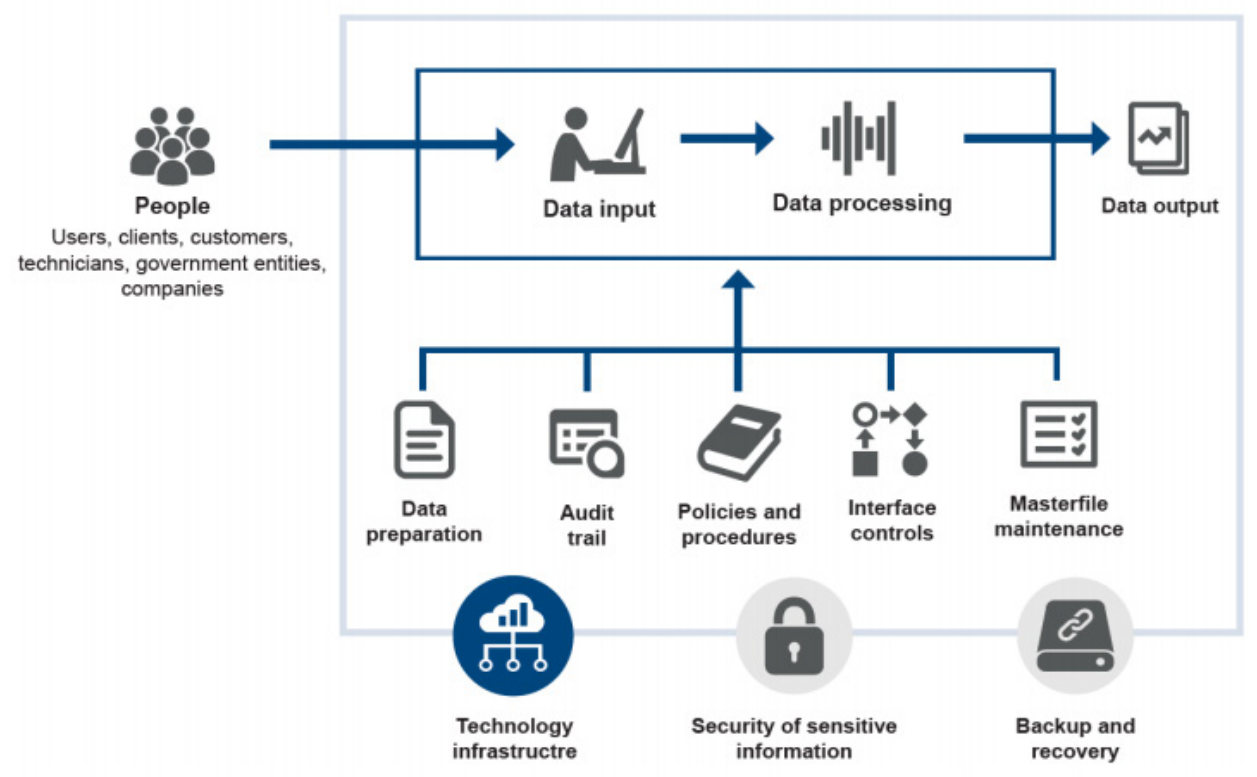

Figure 1. Key elements of focus for application audits

Source: Jordan Langford-Smith J., Aslam K., Tilbrook P., Bakhsh F., (2021), Western Australian Auditor General's Report, Application Controls Audits 2021, Office of the Auditor General Western Australia 
Wood et al (2013) stated that General controls (see Figure 2) cover all business processes, business units, and the IT environment that includes application controls. Application controls are specific to a business process, and each business process supports a business unit. A given business process may support several business units. For publicly traded and other Sarbanes-Oxley compliant companies, the tests are suitable for both business processes and the IT environment. Consistent with the IT environment and business processes, financial reporting objectives, asset claims, completeness, rights and obligations, accuracy, limits and classifications must meet financial requirements.

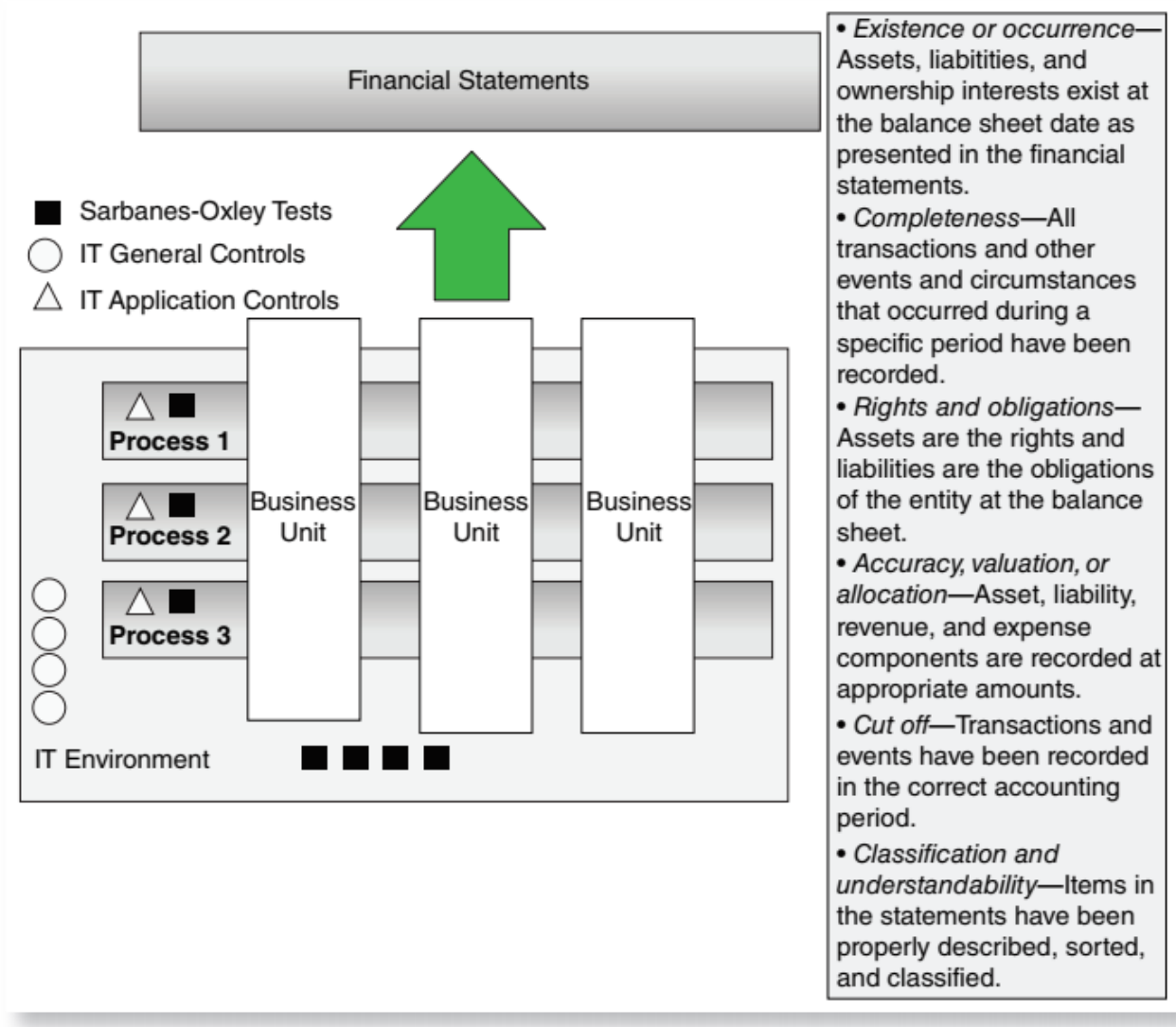

Figure 2. IT General and Application Controls

Source: Wood, J., Brown, W., \& Howe, H. (2013). IT Auditing and Application Controls for Small and Mid-Sized Enterprises: Revenue, Expenditure, Inventory, Payroll, and More (Vol. 573). John Wiley \& Sons.

\section{IT Application Control Tests for a Manufacturing Company}

\subsection{Research Type and Approach}

The aim of the research is to show the effect of the IT General Environment Control (ITGC) and IT Application control (ITAC) on the audit process and on audit evidence. For this aim, we have selected a company from the automotive industry. The Company uses information technology widely in its operations. The company's IT environment has a direct effect on the Company's strategies and business. The company's ERP system is SAP. We have performed ITGC and ITAC audits on the Company's data.

\subsection{Analysis and Findings}

Due to the fact that relying on application controls depends directly on the design and operating effectiveness of the ITGCs, IT General Control procedures have been performed for the company.

Our review of the IT General Controls covers the following areas: 


\section{Manage Access}

Program change management controls.

\section{Manage IT Operations}

The work performed resorted to various methods of information gathering over the IT environment. These are:

- Meeting with Management,

- Analysis of the documentation provided, and

- Discussion of the key findings with management.

The result of the ITGCs risk procedures and results have been summarized in Table 4.

\begin{tabular}{|c|c|c|c|}
\hline IT process & Risks & ITGC Tested & Results \\
\hline \multirow{2}{*}{ Manage Access } & \multirow{2}{*}{$\begin{array}{l}\text { Users of the IT environment aren't } \\
\text { the intended users due to inadequate } \\
\text { authentication and security settings. }\end{array}$} & $\begin{array}{l}\text { Passwords application and security } \\
\text { configurations } \\
\text { have been tested. }\end{array}$ & Effective \\
\hline & & $\begin{array}{l}\text { Passwords to system resources and utilities } \\
\text { and security configurations have been tested. }\end{array}$ & Effective \\
\hline Manage Access & $\begin{array}{l}\text { Users of the IT environment are not } \\
\text { authorized. }\end{array}$ & $\begin{array}{l}\text { User access to the application (creation/ } \\
\text { modification) have been tested. }\end{array}$ & Effective \\
\hline \multirow{3}{*}{ Manage Access } & \multirow{3}{*}{$\begin{array}{l}\text { Unauthorized access to data. Critical } \\
\text { actions launched by unauthorized people } \\
\text { (configuration, development, access } \\
\text { management...). }\end{array}$} & $\begin{array}{l}\text { Access to privileged application has been } \\
\text { tested. }\end{array}$ & Effective \\
\hline & & $\begin{array}{l}\text { User accounts to system resources and utilities } \\
\text { have been appropriately reviewed. }\end{array}$ & Effective \\
\hline & & $\begin{array}{l}\text { User accounts to system resources and utilities } \\
\text { (OS/DB) have been appropriately removed } \\
\text { when no longer required. }\end{array}$ & Ineffective \\
\hline $\begin{array}{l}\text { Change Management } \\
\text { Control }\end{array}$ & $\begin{array}{l}\text { Programs in production are not } \\
\text { secured permitting developers to move } \\
\text { unauthorized or untested changes into the } \\
\text { production environment. }\end{array}$ & $\begin{array}{l}\text { Segregation of incompatible duties exists } \\
\text { within the change management environment. }\end{array}$ & Effective \\
\hline $\begin{array}{l}\text { Change Management } \\
\text { Control }\end{array}$ & $\begin{array}{l}\text { New IT application programs or changes } \\
\text { to the production IT application programs } \\
\text { (including reports and interfaces) are not } \\
\text { appropriate for the business or the IT } \\
\text { environment. }\end{array}$ & Client openings have been tested. & Effective \\
\hline $\begin{array}{l}\text { Manage IT } \\
\text { Operations }\end{array}$ & $\begin{array}{l}\text { Issues with programs that cannot process } \\
\text { to completion are not addressed or are } \\
\text { addressed inappropriately. }\end{array}$ & $\begin{array}{l}\text { Critical jobs of the IT application have been } \\
\text { monitored. }\end{array}$ & Effective \\
\hline \multirow{2}{*}{$\begin{array}{l}\text { Manage IT } \\
\text { Operations }\end{array}$} & \multirow{2}{*}{$\begin{array}{l}\text { Hardware or software issues result in } \\
\text { loss of data or the ability to accurately } \\
\text { process that data. }\end{array}$} & $\begin{array}{l}\text { Backup of the IT application has been } \\
\text { performed and monitored. }\end{array}$ & Effective \\
\hline & & $\begin{array}{l}\text { Incidents related to the IT application have } \\
\text { been addressed in a timely manner. }\end{array}$ & Effective \\
\hline
\end{tabular}

Based on our review, we have not identified significant weaknesses which could significantly threaten IT reliability in respect to the production of financial information. As a consequence, we can rely on the IT General Controls of the IT environment. After relying on ITGCs, we designed and deployed critical controls based on the SAP. The Critical control and testing of ITAC testing procedures and results and the effect of the audit evidence have been summarized in Table 5. 


\begin{tabular}{|c|c|c|}
\hline Control Activity & Testing procedure & Testing results /Effect of the Audit Evidence \\
\hline $\begin{array}{l}\text { Manual journal entries should only } \\
\text { be posted to document types which } \\
\text { are configured in the SAP system. }\end{array}$ & $\begin{array}{l}\text { We examined the configuration } \\
\text { of the system, in order to verify } \\
\text { that the settings found in the } \\
\text { system correspond to those } \\
\text { described in the definition of the } \\
\text { control. }\end{array}$ & $\begin{array}{l}\text { Result: No exception noted } \\
\text { Quality of audit evidence compared to traditional audit } \\
\text { approach: } \\
\text { The auditor can check the manual journal on a sample base in } \\
\text { a traditional audit approach. The sample base control does not } \\
\text { give full assurance. With this ITAC procedure, the auditor can } \\
\text { check all entries. So, the audit evidence obtained by using this } \\
\text { ITAC procedure is of higher quality than that obtained from a } \\
\text { traditional audit. }\end{array}$ \\
\hline $\begin{array}{l}\text { General Ledger }(\mathrm{G} / \mathrm{L}) \text { accounts in } \\
\text { the SAP system are appropriately } \\
\text { configured to only allow automatic } \\
\text { postings. }\end{array}$ & $\begin{array}{l}\mathrm{G} / \mathrm{L} \text { accounts which have been } \\
\text { designated as automatic post } \\
\text { only. }\end{array}$ & $\begin{array}{l}\text { Result: No Exception noted } \\
\text { Quality of audit evidence compared to traditional audit } \\
\text { approach: } \\
\text { The auditor can check the automatic journal on a sample base } \\
\text { in a traditional audit approach. The sample base control does } \\
\text { not give full assurance. With this ITAC Procedure, the auditor } \\
\text { can check all automatic entries. So, the audit evidence obtained } \\
\text { by using this ITAC procedure is of higher quality than that } \\
\text { obtained from a traditional audit. }\end{array}$ \\
\hline $\begin{array}{l}\text { Posting periods in the SAP system } \\
\text { are configured to prevent the } \\
\text { periods in which postings can be } \\
\text { made to the general ledger. }\end{array}$ & $\begin{array}{l}\text { We have analyzed the open/close } \\
\text { posting periods transaction to } \\
\text { ensure the correct and justified } \\
\text { use of this transaction. }\end{array}$ & $\begin{array}{l}\text { Result: No Exception noted } \\
\text { Quality of audit evidence compared to traditional audit } \\
\text { approach: } \\
\text { The cut-off risk is a high risk in the audit approach. The auditor } \\
\text { can perform cut off testing on a sample base in a traditional } \\
\text { audit approach. The sample base control does not give full } \\
\text { assurance. With this ITAC procedure, the auditor can check all } \\
\text { cut-off transactions. So, the audit evidence obtained by using } \\
\text { this ITAC procedure is of higher quality than that obtained } \\
\text { from a traditional audit. By this way, the auditor can reduce the } \\
\text { high risk to a standard risk. }\end{array}$ \\
\hline $\begin{array}{l}\mathrm{G} / \mathrm{L} \text { accounts in the SAP system } \\
\text { are configured with the appropriate } \\
\text { posting blocks and deletion flags. }\end{array}$ & $\begin{array}{l}\text { We have analyzed the G/L } \\
\text { account master data to } \\
\text { determine if accounts have been } \\
\text { appropriately defined as marked } \\
\text { for deletion and/or blocked for } \\
\text { posting. }\end{array}$ & $\begin{array}{l}\text { Result: No Exception noted } \\
\text { Quality of audit evidence compared to traditional audit } \\
\text { approach: } \\
\text { The auditor cannot perform any testing for deletion and posting } \\
\text { transactions. With this ITAC procedure, the auditor can perform } \\
\text { testing for these transactions. The audit evidence obtained by } \\
\text { using this ITAC process is of higher quality. By this way, the } \\
\text { auditor can reduce fraud risk. }\end{array}$ \\
\hline $\begin{array}{l}\text { One-time customer use is } \\
\text { restricted. }\end{array}$ & $\begin{array}{l}\text { We examined the configuration } \\
\text { of the system, in order to verify } \\
\text { that the settings found in the } \\
\text { system correspond to those } \\
\text { described in the definition of the } \\
\text { control. }\end{array}$ & $\begin{array}{l}\text { Result: No Exception noted } \\
\text { Quality of audit evidence compared to traditional audit } \\
\text { approach: } \\
\text { The auditor can perform testing for this procedure on a sample } \\
\text { base in a traditional audit approach. The sample base control } \\
\text { does not give full assurance. With this ITAC procedure, the } \\
\text { auditor can check all restriction customers. So, the audit } \\
\text { evidence obtained by using this ITAC procedure is of higher } \\
\text { quality than that obtained from a traditional audit. }\end{array}$ \\
\hline
\end{tabular}




\begin{tabular}{|c|c|c|}
\hline Control Activity & Testing procedure & Testing results /Effect of the Audit Evidence \\
\hline $\begin{array}{l}\text { Customer master data modification } \\
\text { is secured. }\end{array}$ & $\begin{array}{l}\text { Ensure that all customer } \\
\text { creations/modifications are } \\
\text { secure and respect the standard } \\
\text { procedure define by the group. }\end{array}$ & $\begin{array}{l}\text { Result: No Exception noted } \\
\text { Quality of audit evidence compared to traditional audit } \\
\text { approach: } \\
\text { The auditor can perform testing for this procedure on a sample } \\
\text { base in a traditional audit approach. The sample base control } \\
\text { does not give full assurance. With this ITAC procedure, the } \\
\text { auditor can check all customers that have been created comply } \\
\text { with standard procedures. So, the audit evidence obtained } \\
\text { by using this ITAC procedure is of higher quality than that } \\
\text { obtained from a traditional audit. }\end{array}$ \\
\hline $\begin{array}{l}\text { Copy controls have been } \\
\text { configured in the SAP system to } \\
\text { correctly copy quantity information } \\
\text { from the (source) sales order } \\
\text { document through to the (target) } \\
\text { billing document: price and } \\
\text { quantity. }\end{array}$ & $\begin{array}{l}\text { We examined the configuration } \\
\text { of the system, in order to verify } \\
\text { that the settings found in the } \\
\text { system correspond to those } \\
\text { described in the definition of the } \\
\text { control. }\end{array}$ & $\begin{array}{l}\text { Result: No Exception noted } \\
\text { Quality of audit evidence compared to traditional audit } \\
\text { approach: } \\
\text { The auditor can perform testing for this procedure on a sample } \\
\text { base in a traditional audit approach. The sample base control } \\
\text { does not give full assurance. With this ITAC procedure, the } \\
\text { auditor can check all order forms and billing documents. So, } \\
\text { the audit evidence obtained by using this ITAC procedure is of } \\
\text { higher quality than that obtained from a traditional audit. }\end{array}$ \\
\hline Over delivery is limited. & $\begin{array}{l}\text { We have identified and justify } \\
\text { all customers allowed to perform } \\
\text { over deliveries in the system. }\end{array}$ & $\begin{array}{l}\text { Result: Exceptions noted } \\
\text { Quality of audit evidence compared to traditional audit } \\
\text { approach: } \\
\text { This ITAC control procedure shows that delivery notes are not } \\
\text { limited. So, the auditor does not get more quality evidence and } \\
\text { should perform more substantive testing for this risk. }\end{array}$ \\
\hline $\begin{array}{l}\text { Deliveries are systematically linked } \\
\text { to valid orders. }\end{array}$ & $\begin{array}{l}\text { We have verified that there are } \\
\text { no outbound delivery documents } \\
\text { with an impact on the G/L } \\
\text { accounts that can be created } \\
\text { without referring to a sales order } \\
\text { document. }\end{array}$ & $\begin{array}{l}\text { Result: Exception noted } \\
\text { Quality of audit evidence compared to traditional audit } \\
\text { approach: } \\
\text { This ITAC control shows that delivery notes are not } \\
\text { systematically linked to valid orders So, the auditor does not } \\
\text { get a higher quality of evidence and should perform more } \\
\text { substantive testing for this risk. }\end{array}$ \\
\hline $\begin{array}{l}\text { Deliveries are systematically } \\
\text { invoiced. }\end{array}$ & $\begin{array}{l}\text { We have noted that every week, } \\
\text { a report from SAP is extracted in } \\
\text { order to monitor the deliveries } \\
\text { not invoiced. }\end{array}$ & $\begin{array}{l}\text { Result: No Exception noted } \\
\text { Quality of audit evidence compared to traditional audit } \\
\text { approach: } \\
\text { The auditor can perform testing for this procedure on a sample } \\
\text { base in a traditional audit approach. The sample base control } \\
\text { does not give full assurance. With this ITAC procedure, the } \\
\text { auditor can check all invoices. So, the audit evidence obtained } \\
\text { by using this ITAC procedure is of higher quality than that } \\
\text { obtained from a traditional audit. }\end{array}$ \\
\hline
\end{tabular}




\begin{tabular}{|c|c|c|}
\hline Control Activity & Testing procedure & Testing results /Effect of the Audit Evidence \\
\hline $\begin{array}{l}\text { Copy controls in the SAP system } \\
\text { are configured to copy information } \\
\text { from the (source) sales order } \\
\text { document through to the (target) } \\
\text { delivery document, ensuring } \\
\text { crucial information (such as items } \\
\text { and order requirements) is copied } \\
\text { onto the delivery document. }\end{array}$ & $\begin{array}{l}\text { We have reviewed the system } \\
\text { configuration in order to } \\
\text { ensure the consistency of the } \\
\text { information between the sales } \\
\text { document and the delivery } \\
\text { document on quantity and price. }\end{array}$ & $\begin{array}{l}\text { Result: No Exception noted } \\
\text { Quality of audit evidence compared to traditional audit } \\
\text { approach: } \\
\text { The auditor can't control all mathematical controls between } \\
\text { the sales document and delivery document in a traditional audit } \\
\text { approach. The sample base control does not give full assurance. } \\
\text { With this ITAC procedure, the auditor can check all invoices. } \\
\text { So, the audit evidence obtained by using this ITAC procedure is } \\
\text { of higher quality than that obtained from a traditional audit. }\end{array}$ \\
\hline $\begin{array}{l}\text { Cut off is enforced (goods issue } \\
\text { date / invoice date). }\end{array}$ & $\begin{array}{l}\text { Report and processes are in place } \\
\text { to analyze, monitor, share, alert } \\
\text { and escalate open items. The } \\
\text { report is extracted from SAP and } \\
\text { all exceptions are justified. }\end{array}$ & $\begin{array}{l}\text { Result: No Exception noted } \\
\text { Quality of audit evidence compared to traditional audit } \\
\text { approach: } \\
\text { The cut-off risk is a high risk in an audit approach. The auditor } \\
\text { can perform cut off testing on a sample base in a traditional } \\
\text { audit approach. The sample base control does not give full } \\
\text { assurance. With this ITAC procedure, the auditor can check all } \\
\text { cut-off transactions. So, the audit evidence obtained by using } \\
\text { this ITAC procedure is of higher quality than that obtained } \\
\text { from a traditional audit. By this way, the auditor can reduce the } \\
\text { high risk to a standard risk. }\end{array}$ \\
\hline Due invoices list is monitored. & $\begin{array}{l}\text { Report and processes in place to } \\
\text { analyze, monitor, share, alert and } \\
\text { escalate open items. The report } \\
\text { is extracted from SAP and all } \\
\text { exceptions are justified. }\end{array}$ & $\begin{array}{l}\text { Result: No Exception noted } \\
\text { Quality of audit evidence compared to traditional audit } \\
\text { approach: } \\
\text { The Auditor can perform this testing on a sample base in a } \\
\text { traditional audit approach. The sample base control does not } \\
\text { give full assurance. With this ITAC procedure, the auditor can } \\
\text { check all due invoices. So, the audit evidence obtained by using } \\
\text { this ITAC process is of higher quality than that obtained from a } \\
\text { traditional audit. }\end{array}$ \\
\hline $\begin{array}{l}\text { The provision for doubtful clients } \\
\text { is calculated and reviewed. }\end{array}$ & $\begin{array}{l}\text { Report from SAP to identify the } \\
\text { provision for doubtful clients. } \\
\text { At the end of the month the } \\
\text { amount from doubtful clients is } \\
\text { calculated and monitored. }\end{array}$ & $\begin{array}{l}\text { Result: No Exception noted } \\
\text { Quality of audit evidence compared to traditional audit } \\
\text { approach: } \\
\text { The Auditor can perform this testing on a sample base in a } \\
\text { traditional audit approach. The sample base control does not } \\
\text { give full assurance. With this ITAC procedure, the auditor can } \\
\text { check all doubtful clients. So, the audit evidence obtained by } \\
\text { using this ITAC process is of higher quality than that obtained } \\
\text { from a traditional audit. }\end{array}$ \\
\hline $\begin{array}{l}\text { Credit notes are blocked before } \\
\text { posting. }\end{array}$ & $\begin{array}{l}\text { No value in order to identify the } \\
\text { documents with no preceding } \\
\text { documents defined }\end{array}$ & $\begin{array}{l}\text { Result: No Exception noted } \\
\text { Quality of audit evidence compared to traditional audit } \\
\text { approach: } \\
\text { The Auditor can perform this testing on a sample base in a } \\
\text { traditional audit approach. The sample base control does not } \\
\text { give full assurance. With this ITAC procedure, the auditor can } \\
\text { check all credit notes. So, the audit evidence obtained by using } \\
\text { this ITAC procedure is of higher quality than that obtained } \\
\text { from a traditional audit. }\end{array}$ \\
\hline
\end{tabular}




\begin{tabular}{|c|c|c|}
\hline Control Activity & Testing procedure & Testing results /Effect of the Audit Evidence \\
\hline $\begin{array}{l}\text { Account determination in the } \\
\text { SAP system is configured to } \\
\text { automatically post to the inventory } \\
\text { GL account upon goods issued. }\end{array}$ & $\begin{array}{l}\text { We have verified that the chart } \\
\text { of accounts allowing automatic } \\
\text { posting upon goods is associated } \\
\text { with accounts beginning with } \\
\text { "3". }\end{array}$ & $\begin{array}{l}\text { Result: No Exception noted } \\
\text { Quality of audit evidence compared to traditional audit } \\
\text { approach: } \\
\text { The Auditor can perform this testing on a sample base in a } \\
\text { traditional audit approach. The sample base control does not } \\
\text { give full assurance. With this ITAC procedure, the auditor } \\
\text { can check all automatic posts. So, the audit evidence obtained } \\
\text { by using this ITAC procedure is of higher quality than that } \\
\text { obtained from a traditional audit. }\end{array}$ \\
\hline $\begin{array}{l}\text { Invoice tolerances in the SAP } \\
\text { system are configured to prevent } \\
\text { payment of an invoice where } \\
\text { the price per unit exceeds the } \\
\text { purchase order price per unit by an } \\
\text { appropriately defined tolerance. }\end{array}$ & $\begin{array}{l}\text { We have checked the table } \\
\text { and verified that configured } \\
\text { tolerances are in line with the } \\
\text { company's procedures. }\end{array}$ & $\begin{array}{l}\text { Result: No Exception noted } \\
\text { Quality of audit evidence compared to traditional audit } \\
\text { approach: } \\
\text { The Auditor can perform this testing on sample base in a } \\
\text { traditional audit approach. The sample base control does not } \\
\text { give full assurance. With this ITAC procedure, the auditor can } \\
\text { check all invoice and purchase orders. So, the audit evidence } \\
\text { obtained by using this ITAC procedure is of higher quality than } \\
\text { that obtained from a traditional audit. }\end{array}$ \\
\hline $\begin{array}{l}\text { Account determination in the } \\
\text { SAP system is configured to the } \\
\text { appropriate revenue general ledger } \\
\text { account. }\end{array}$ & $\begin{array}{l}\text { We have verified that the chart } \\
\text { of accounts related to revenue } \\
\text { begins with "7" Group. }\end{array}$ & $\begin{array}{l}\text { Result: No Exception noted } \\
\text { Quality of audit evidence compared to traditional audit } \\
\text { approach: } \\
\text { The Auditor can perform this testing on a sample base in a } \\
\text { traditional audit approach. The sample base control does not } \\
\text { give full assurance. With this ITAC procedure, the auditor can } \\
\text { check all tolerances. So, the audit evidence obtained by using } \\
\text { this ITAC procedure is of higher quality than that obtained } \\
\text { from a traditional audit. }\end{array}$ \\
\hline $\begin{array}{l}\text { Invoice tolerances in the SAP } \\
\text { system are configured to prevent } \\
\text { payment of an invoice where } \\
\text { the quantity invoiced exceeds } \\
\text { the goods receipt quantity by an } \\
\text { appropriately defined tolerance. }\end{array}$ & $\begin{array}{l}\text { We have verified that configured } \\
\text { tolerances are in line with } \\
\text { procedures. }\end{array}$ & $\begin{array}{l}\text { Result: No Exception noted } \\
\text { Quality of audit evidence compared to traditional audit } \\
\text { approach: } \\
\text { The Auditor can perform this testing on a sample base in a } \\
\text { traditional audit approach. The sample base control does not } \\
\text { give full assurance. With this ITAC procedure, the auditor can } \\
\text { check all tolerances. So, the audit evidence obtained by using } \\
\text { this ITAC procedure is of higher quality than that obtained } \\
\text { from a traditional audit. }\end{array}$ \\
\hline $\begin{array}{l}\text { Account determination in the } \\
\text { SAP system is configured to } \\
\text { automatically post to the liability } \\
\text { suspense account (GR/IR) upon } \\
\text { goods receipt and invoice receipt. }\end{array}$ & $\begin{array}{l}\text { We have verified that GR/IR } \\
\text { clearing accounts to which Good } \\
\text { Receipt and Invoice receipt } \\
\text { movement types are connected } \\
\text { do not access manual entries. }\end{array}$ & $\begin{array}{l}\text { Result: No Exception noted } \\
\text { Quality of audit evidence compared to traditional audit } \\
\text { approach: } \\
\text { The auditor can perform this testing on a sample base in a } \\
\text { traditional audit approach. The sample base control does not } \\
\text { give full assurance. With this ITAC procedure, the auditor can } \\
\text { check the liability suspense account. So, the audit evidence } \\
\text { obtained by using this ITAC procedure is of higher quality than } \\
\text { that obtained from a traditional audit. }\end{array}$ \\
\hline
\end{tabular}




\begin{tabular}{|c|c|c|}
\hline \begin{tabular}{|l|} 
Control Activity \\
\end{tabular} & Testing procedure & Testing results /Effect of the Audit Evidence \\
\hline $\begin{array}{l}\text { Upon entry of purchase invoices, } \\
\text { the system automatically checks } \\
\text { whether the invoice is already } \\
\text { present in the system. In case of } \\
\text { duplicates, the system will provide } \\
\text { a warning message. The system } \\
\text { does not allow the payment of } \\
\text { blocked invoices. }\end{array}$ & $\begin{array}{l}\text { Checking that for the vendors } \\
\text { groups for in-scope entities, } \\
\text { the double invoice check is } \\
\text { activated. }\end{array}$ & $\begin{array}{l}\text { Result: No Exception noted } \\
\text { Quality of audit evidence compared to traditional audit } \\
\text { approach: } \\
\text { The auditor can perform this testing on a sample base in a } \\
\text { traditional audit approach. The sample base control does not } \\
\text { give full assurance. With this ITAC procedure, the auditor can } \\
\text { check the liability suspense account. So, the audit evidence } \\
\text { obtained by using this ITAC procedure is of higher quality than } \\
\text { that obtained from a traditional audit. }\end{array}$ \\
\hline $\begin{array}{l}\text { In case of litigation as a result } \\
\text { of price differences, the invoice } \\
\text { is recorded on reception of the } \\
\text { invoice whatever the difference, } \\
\text { and the difference is recorded in } \\
\text { a specific account of purchases } \\
\text { expenses \#. } \\
\text { The system automatically blocks } \\
\text { the invoice and sends the invoice } \\
\text { for approval. }\end{array}$ & $\begin{array}{l}\text { Checking the parameterizing and } \\
\text { performing tests of one related } \\
\text { to: } \\
-\quad \text { Differences between } \\
\text { Invoice and Purchase Order } \\
\text { Rounding / minor differences } \\
\text { within the invoice }\end{array}$ & $\begin{array}{l}\text { Result: No Exception noted } \\
\text { Quality of audit evidence compared to traditional audit } \\
\text { approach: } \\
\text { The auditor can perform this testing on a sample base in a } \\
\text { traditional audit approach. The sample base control does not } \\
\text { give full assurance. With this ITAC procedure, the auditor } \\
\text { can check liability price differences. So, the audit evidence } \\
\text { obtained by using this ITAC procedure is of higher quality than } \\
\text { that obtained from a traditional audit. }\end{array}$ \\
\hline $\begin{array}{l}\text { Account determination in the SAP } \\
\text { system is configured to ensure } \\
\text { the appropriate inventory account } \\
\text { is updated during goods receipt } \\
\text { processing. }\end{array}$ & $\begin{array}{l}\text { Verifying that stock accounts to } \\
\text { which Good Receipt movement } \\
\text { types are connected do not } \\
\text { access manual entries. }\end{array}$ & $\begin{array}{l}\text { Result: No Exception noted } \\
\text { Quality of audit evidence compared to traditional audit } \\
\text { approach: } \\
\text { The auditor can perform this testing on a sample base in a } \\
\text { traditional audit approach. The sample base control does not } \\
\text { give full assurance. With this ITAC procedure, the auditor can } \\
\text { check the inventory account. So, the audit evidence obtained } \\
\text { by using this ITAC procedure is of higher quality than that } \\
\text { obtained from a traditional audit. }\end{array}$ \\
\hline $\begin{array}{l}\text { The invoices are automatically } \\
\text { blocked in the system until the } \\
\text { approval workflow is concluded. }\end{array}$ & $\begin{array}{l}\text { We have performed standard } \\
\text { configuration tests in SAP. }\end{array}$ & $\begin{array}{l}\text { Result: No Exception noted } \\
\text { Quality of audit evidence compared to traditional audit } \\
\text { approach: } \\
\text { The auditor can perform this testing on a sample base in a } \\
\text { traditional audit approach. The sample base control does not } \\
\text { give full assurance. With this ITAC procedure, the auditor can } \\
\text { check all automatically blocked invoices. So, the audit evidence } \\
\text { obtained by using this ITAC procedure is of higher quality than } \\
\text { that obtained from a traditional audit. }\end{array}$ \\
\hline $\begin{array}{l}\text { The access to supplier master } \\
\text { data (regarding IBAN changes) is } \\
\text { restricted to the appropriate users. }\end{array}$ & $\begin{array}{l}\text { Exhaustive analysis of users } \\
\text { having performed suppliers } \\
\text { IBAN changes during FY20. }\end{array}$ & $\begin{array}{l}\text { Result: No Exception noted } \\
\text { Quality of audit evidence compared to traditional audit } \\
\text { approach: } \\
\text { The auditor can perform this testing on a sample base in a } \\
\text { traditional audit approach. The sample base control does not } \\
\text { give full assurance. With this ITAC procedure, the auditor can } \\
\text { check all supplier master data. So, the audit evidence obtained } \\
\text { by using this ITAC procedure is of higher quality than that } \\
\text { obtained from a traditional audit. }\end{array}$ \\
\hline
\end{tabular}




\begin{tabular}{|c|c|c|}
\hline Control Activity & Testing procedure & Testing results /Effect of the Audit Evidence \\
\hline $\begin{array}{l}\text { The SAP does not allow the } \\
\text { payment of blocked invoices. }\end{array}$ & $\begin{array}{l}\text { We have performed standard } \\
\text { configuration tests in SAP. }\end{array}$ & $\begin{array}{l}\text { Result: No Exception noted } \\
\text { Quality of audit evidence compared to traditional audit } \\
\text { approach: } \\
\text { The auditor can perform this testing on a sample base in a } \\
\text { traditional audit approach. The sample base control does not } \\
\text { give full assurance. With this ITAC procedure, the auditor } \\
\text { can check blocked invoices. So, the audit evidence obtained } \\
\text { by using this ITAC procedure is of higher quality than that } \\
\text { obtained from a traditional audit. }\end{array}$ \\
\hline $\begin{array}{l}\text { The SAP does not allow the change } \\
\text { of the due date by the person who } \\
\text { prepare the payment proposal. }\end{array}$ & $\begin{array}{l}\text { We have performed standard } \\
\text { configuration tests in SAP. }\end{array}$ & $\begin{array}{l}\text { Result: No Exception noted } \\
\text { Quality of audit evidence compared to traditional audit } \\
\text { approach: } \\
\text { The auditor can't perform this testing in a traditional audit } \\
\text { approach. With this ITAC procedure, the auditor can check } \\
\text { blocked invoices. So, the audit evidence obtained by using this } \\
\text { ITAC procedures is of higher quality than that obtained from a } \\
\text { traditional audit. }\end{array}$ \\
\hline
\end{tabular}

As result of IT application control summarized in Table 5, we concluded that, IT application control is a great opportunity for auditors to improve their knowledge of the company and to reduce manual substantive testing that the auditor should perform. With ITAC procedures, the auditor can perform testing on all transactions instead of a sample base control. The auditor can take more quality data compared to a traditional audit approach. With the increase in the complexity of companies, performing manual substantive tests can be time-consuming for the auditor and cannot give sufficient reliable audit evidence for the auditor. With an IT Application Control audit, the auditor can provide more reliable, higher quality audit evidence.

\section{Discussion}

Parallel to these investments in IT, financial reporting processes have undergone serious changes. While financial reporting processes could be managed using a single application in the past, nowadays, all items that are based on financial statements have begun to be managed with different applications integrated into IT. In addition to the creation of all accounting records that the bases of financial statement items with different IT applications, factors such as the expansion and diversification of companies' operations have made it difficult to audit the accounting records with classical methods. In this study, using data on an automotive industry company, we have examined the effects of ITAC on an audit. Firstly, we have performed ITGC procedures on an ERP system. Based on our review on the IT general environment, we have not identified significant weaknesses which could significantly threaten IT reliability in respect to the production of financial information. Therefore, we concluded that, we can rely on the IT General Controls of the IT environment. After relying on the ITGC system, we have determined the critical business control of the ERP system, and we have performed an ITAC audit on those critical controls and we have collected audit evidence from the systems. We have concluded that ITAC and ITGC audit procedures provide stronger audit evidence with respect to the classic audit approach. IT application control is a great opportunity for auditors to improve their knowledge of the company and to reduce manual substantive testing that the auditor should perform. With the increase in complexity of companies, performing manual substantive testing can be time-consuming for the auditor and cannot give sufficient reliable audit evidence for the auditor. In future studies, researchers can investigate the relationship between ITAC control and using artificial intelligence in audit procedures, which is a further step in audit methodology. 
Hakem Değerlendirmesi: Dış bağımsız.

Çıkar Çatışması: Yazar çıkar çatışması bildirmemiştir.

Finansal Destek: Yazar bu çalışma için finansal destek almadığını beyan etmiştir.

Yazar Katkıları: Çalışma Konsepti/Tasarım- N.K., A.A.S.; Veri Toplama- ; Veri Analizi/Yorumlama- N.K., A.A.S.; Yazı Taslağı- N.K., A.A.S.; İçeriğin Eleştirel İncelemesi- N.K., A.A.S.; Son Onay ve Sorumluluk- N.K., A.A.S.

Peer-review: Externally peer-reviewed.

Conflict of Interest: The author has no conflict of interest to declare

Grant Support: The author declared that this study has received no financial support.

Author Contributions: Conception/Design of Study- N.K., A.A.S.; Data Acquisition- N.K., A.A.S.; Data Analysis/Interpretation- N.K., A.A.S.; Drafting Manuscript- N.K., A.A.S.; Critical Revision of Manuscript- N.K., A.A.S.; Final Approval and Accountability- N.K., A.A.S.

\section{References}

Bellino, C., Hunt, S., \& Wells, J. (2007). Auditing application controls. Altamonte Springs: IIA.

Chen, W., Smieliauskas, W. J., \& Trippen, G. (2011, October). An audit evidence gathering model in online auditing environments. In 2011 IEEE International Conference on Systems, Man, and Cybernetics (pp. 1448-1452). IEEE.

Fowler, R. B., \& Mar, S. (2017). Application control testing: control reviews can help ensure critical software applications function effectively and securely. Internal Auditor, 74(3), 18-20.

Henderson III, D. L., Davis, J. M., \& Lapke, M. S. (2013). The effect of internal auditors' information technology knowledge on integrated internal audits. International Business Research, 6(4), 147.

Jakšić, D. (2009). Implementation of computer assisted audit techniques in application controls testing. Management Information Systems, 4(1), 9-12.

Jordan Langford-Smith J., Aslam K., Tilbrook P., Bakhsh F., (2021), Western Australian Auditor General's Report, Application Controls Audits 2021, Office of the Auditor General Western Australia

Karya, G., \& Moertini, V. S. (2013). The Customization of the ISACA's Framework as an Audit Model for Large Scale (Enterprise) Web Applications. ISICO 2013, 2013.

Padayachee, L. G., \& De Jager, H. (2015). Integrated auditing-an internal audit perspective. Southern African Journal of Accountability and Auditing Research, 17(2), 47-56.

Sayana, S. A. (2002). Auditing General and application controls. Information Systems Control Journal, 5, 16-19.

Wood, J., Brown, W., \& Howe, H. (2013). IT Auditing and Application Controls for Small and Mid-Sized Enterprises: Revenue, Expenditure, Inventory, Payroll, and More (Vol. 573). John Wiley \& Sons. 
